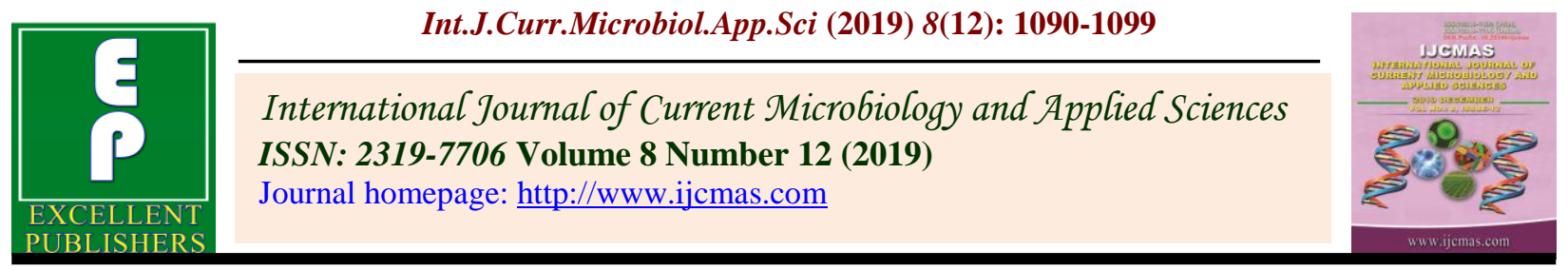

Original Research Article

https://doi.org/10.20546/ijcmas.2019.812.138

\title{
Heterosis and Combining Ability Analysis for Seed Yield and its Attributes in Indian Mustard [Brassica juncea (L.) Czern and Coss]
}

\author{
Vidyut Kumar Saikia $^{1}$, Rumjhum Phukan ${ }^{1 *}$, Hrishikesh Ojah ${ }^{1}$, Purna Kanta Barua ${ }^{1}$, \\ Meghali Barua ${ }^{1}$ and Prakash Kalita ${ }^{2}$ \\ ${ }^{1}$ Department of PBG, Assam Agricultural University, Jorhat-13, India \\ ${ }^{2}$ Department of Crop Physiology, Assam Agricultural University, Jorhat-13, India \\ *Corresponding author
}

\section{A B S T R A C T}

Keywords

Indian mustard,

Diallel, Heterosis,

GCA, SCA,

Variance

Article Info

Accepted:

10 November 2019

Available Online:

10 December 2019
A set of 4 diverse parental lines were crossed in diallel mating design without reciprocals to study the combining ability and heterosis for yield and yield attributes in Indian mustard [Brassica juncea (L.) Czern and Coss] during rabi 2017-18. All the $F_{1}$ along with parents were evaluated in RBD with three replications. Analysis of variance for combining ability reveals significant variation was present among parents, crosses and among $\mathrm{F}_{1} \mathrm{~s}$ and their parents. Combining ability analysis revealed importance of both additive and nonadditive genetic variances for the control of various traits. From the evaluation of GCA variances in parents, it was observed that Pusa Mahek is a best general combiner for most of the traits, followed by TM-2. Out of the 16 characters studied, seven characters exhibited significant GCA and SCA effects. The best cross combination for $50 \%$ flowering PM-27 x DRMR-150-35, TM-2 x DRMR-150-35 for days to maturity, and PM-27 x Pusa Mahek for plant height. PM-27 x TM-2 was best cross combination showing significantly high SCA and heterosis effect for several yield attributing traits.

\section{Introduction}

Rapeseed and Mustard is the second most important oilseed crop in India after groundnut. India contributes $19.29 \%$ and $11.12 \%$ to the total world acreage and production respectively (USDA, 2013). According to the Government's assessments the total area under Rapeseed-Mustard in India during rabi 2016-17 was 6.7 million hectares with a production of 7.2 million tons and an average productivity of $1069 \mathrm{~kg} / \mathrm{hectare}$ (Anonymous, 2017). With approximately 50\% of the total edible oil being imported, the scenario of India being self sufficient in the field of oil production is a great challenge. To 
mitigate the ever-widening gap of demand and production of edible oil, the development of varieties which perform better and varieties suited to various ecological niches are of utmost importance. Mustard is a species with genetic potential for high economic yield. Mustard plants are much taller than that of toria (Brassica rapa). It has a solid stems unlike toria and has a much higher biological yield than toria. However despite these characteristics, mustard is not a favored crop in Assam because it takes much longer duration to mature and farmers prefer oilseed varieties which are medium to short height and duration. Hence, the development of mustard varieties with medium to short duration with short stature is the need of the hour. It is believed that the yield can be increased by dispensing with the unproductive feet of the mustard plants, i.e., the portion of the main stem from the ground level to the first primary branch, which consumes a considerable proportion of the photosynthates produced by the plant, thus lowering the amount of photosynthates available for conversion to economic product i.e. seed. It was proposed that selection for reduced foot length will lead to short duration and higher yield. From a previous study to assess the genetic diversity among 22 mustard genotypes, four genotypes were selected and an effort was made to study the combining ability, nature of gene action and heterosis involved in expression of 16 quantitative characters by using a $4 \times 4$ half diallel mating design.

\section{Materials and Methods}

In a previous study the genetic diversity of 22 genotypes of mustard was evaluated and four genotypes namely Pusa Mahek, TM-2, PM-27, and DRMR-150-35 were selected and crosses were made in $4 \times 4$ diallel fashion excluding reciprocal during the rabi season of 2016-17. All the 8 crosses along with their parent were evaluated in RBD with three replications in rabi of 2017-18.

Observations were recorded in 10 sample plants in each entry in each replication for grain yield and fifteen other quantitative characters. Data were recorded for days to $50 \%$ flowering, days to maturity, plant height, number of primary branch per plant, number of secondary branch per plant, main shoot length, number of siliqua on main shoot, foot length, maximum root length, stem thickness, number of seeds per siliqua, 1000 seed weight, oil content, biological yield per plant. Harvest index, and seed yield per plant. Days to $50 \%$ flowering and Days to maturity were measured on subplot basis. The arithmetic means of the observation were taken as the plot mean data for statistical analysis.

The general combining ability (GCA) and the specific combining ability (SCA) effects for the diallel mating design was analyzed by adapting Griffings (1956), model-I and Method-2. The average F1 value was used for estimation of heterosis expressed as percentage over better parent.

\section{Results and Discussion}

\section{Estimation of combining ability}

Analysis of variance (ANOVA) (Table 1) for 16 quantitative characters revealed significant variation among the entries. Significant variability existed among the parents as well as crosses for most of the characters studied. This signified that sufficient variation was present among parents, crosses, and between parents and crosses

Combining ability studies are important for identification of parents as well as cross combinations that yield superior segregants. East, Shull and Jones in their classic studies observed that certain genotypes when mated to 
other genotypes produce better hybrids. Sprague and Tatum (1942) defined general combining ability (GCA) as the average performance of a line in a series of hybrid combinations while specific combining ability (SCA) refers to those cases where certain combinations do relatively better or worse than would be expected on the basis of the average performance of the lines involved. The variance arising out of GCA estimates of lines has generally been equated to additive and additive $X$ additive type of gene interaction. Similarly, the variance arising out of SCA estimates of crosses has been equated to non additive gene action (Sprague and Tatum, 1942 and Falconer, 1960).

The characters like early maturity, reduced plant height and length of main axis are preferred in mustard, which enable plant breeders to develop varieties evading or tolerating the abiotic stresses like heat, lodging and at the same allowing the cultivation of a succeeding crop. Therefore, the negative combining ability effects and heterosis are desirable for these traits. The remaining yield attributing characters provide more opportunities for increasing yield and therefore positive combining ability effect and heterosis effects are preferred. TM-2 showed high negative GCA effects for days to maturity and foot length and could be used as a good general combiner for developing varieties with shorter duration and height whereas the variety Pusa Mahek found to be a valuable parent in crosses for most of the yield and yield attributing characters followed by variety DRMR-150-35. These parents could be utilized successfully for subsequent breeding programme. Since higher yields in $F_{1}$ can be attributed to fixable (additive) and/or non fixable (non additive) gene action, the total effect partition of the progeny into general and specific combining ability effects interprets the causes of heterosis (Gupta et al., 2011). In the study the SCA variance exhibited a higher value than the GCA variance for the characters days to maturity, secondary branch number, siliqua on main shoot, seeds per siliqua, thousand seed weight, biological yield per plant, seed yield per plant. This indicated the preponderance of non additive gene action for these traits. Hence the traits can be exploited through heterosis breeding for enhancing the yield of Indian mustard. These findings are in accord with the results of Brandle and Mcvetty (1989) and Teklewood and Becker (2005). Parmer et al., (2011) carried out a study on combining ability was analyzed using a Line $\mathrm{x}$ tester of ten lines and five testers in Indian mustard [Brassica juncea (L.) Czern \& Coss]. Combining ability analysis, on pooled basis, revealed the importance of both additive as well as non-additive genetic variances for control of various traits. Similar results were reported by Shrimali et al., (2016)

Highly significant GCA mean squares were observed for seven characters viz. days to maturity, secondary branch number, siliquae on main shoot, seeds per siliqua, 1000-seed weight, biological yield per plant, and seed yield per plant (Table 2). Also highly significant specific combining ability mean squares were observed for thirteen characters (Table 2). The magnitude of $\sigma^{2}$ (Variance of SCA) is higher than that $\sigma_{g}^{2}$ (Variance of GCA) for the characters days to maturity, secondary branch number, siliqua on main shoot, seeds per siliqua, thousand seed weight, biological yield per plant, seed yield per plant indicating a predominance of non-additive gene action (Table 3). Kumar et al., (2001) conducted a 6 X 6 diallel experiment to estimate the combining ability and heterosis for oil content in toria and found the presence of both additive and non-additive genetic components for oil component. Brar et al., (2006) studied the nature and magnitude of combining ability effects for seed yield, its components and oil content in toria and 
observed that both GCA and SCA effects were significant for all characters. The average degree of dominance was quite high for seed yield per plant, plant height, number of siliquae on main shoot and primary branches, indicating the involvement of non-additive gene effects in controlling the inheritance of these traits

Characters like early flowering and maturity, reduced foot length and reduced length of main axis are desirable traits in mustard. In the study the maximum negative GCA was exhibited by the genotype TM-2 for days to maturity (-1.8) and foot length (-1.98), but positive and significant GCA values were observed for secondary branch number and seeds per siliqua. Pusa Mahek exhibited significant positive GCA effects for the characters secondary branch number (1.02), siliqua on main shoot (2.36), 1000-seed weight (0.24), biological yield per plant (7.45), and seed yield per plant (2.75) and significant negative GCA effects for the character seeds per siliqua (Table 4). The variety DRMR-150-35 exhibited significant positive GCA effect for seeds per siliqua and negative significant GCA effect was exhibited for siliqua on main shoot, 1000-seed weight, and seed yield per plant. The variety PM 27 exhibited significant negative GCA effect for primary branch number, secondary branch number, siliqua on main shoot and thousand seed weight and seed yield per plant. Similar results were reported by Aghao et al., (2010)

The specific combining ability effects of the $\mathrm{F}_{1}$ progeny are presented in Table 5. The maximum negative SCA effects for days to $50 \%$ flowering(-4.34), days to maturity $(-8.11)$ and plant height $(-41.09)$ was exhibited by the cross TM 2 X DRMR 150-359.On the other hand the maximum negative SCA effects for the character mean shoot length $(-21.06)$ was exhibited by the cross PM 27 X Pusa Mahek.
The highest positive SCA effects for secondary branch number (3.58) was exhibited by the cross Pusa Mahek X DRMR 150-35. The cross, PM27 X DRMR-150-35 exhibited the highest positive SCA effects for the character siliqua on main $\operatorname{shoot}(9.53)$ The highest positive SCA effect for the character mean root length (4.42), thousand seed weight (0.97) and harvest index (10.77) was exhibited by the cross PM 27 X TM 2.

\section{Estimation of better parent heterosis}

The estimates of better parent heterosis are presented in Table 6. It was observed that all the six crosses exhibited significant negative heterosis for the character days to $50 \%$ flowering in all the crosses with the highest negative heterosis being exhibited by the cross PM27 X DRMR-150-35 (21.08). Amongst the five crosses which exhibited significant negative heterosis, the cross TM 2 X DRMR 150-35 exhibited the highest negative heterosis effects for the characters days to maturity (13.80) and plant height (41.62). Among the yield attributing characters, highest positive heterosis was recorded for secondary branch number (53.79) in the cross Pusa Mahek X TM 2, siliqua in main shoot (41.69) in the cross PM-27 X DRMR 150-35, maximum root length (65.82) in cross TM $2 \mathrm{X}$ DRMR 150-35 and for harvest index (83.26) in the cross PM 27 X TM 2. Similar findings are in accordance with Thanmichon et al., 2015, Yadav et al., 2012 and Gami et al., 2013. By studying the relationship between genetic divergence and combining ability in Indian mustard Monalisa et al., (2005) reported that medium genetic divergence combined with low or average GCA effect in the parents gave high SCA effects, which corresponded with high heterotic performance and concluded that there should be an optimum level of genetic divergence to obtain economic heterosis in $\mathrm{F}_{1}$ 
Table.1 Analysis of variance (ANOVA) for 16 quantitative characters in Indian mustard

\begin{tabular}{|c|c|c|c|c|c|c|c|c|c|c|c|c|c|c|c|c|c|}
\hline Source & df & FF & DM & PH & $\begin{array}{c}\mathbf{P B} \\
\mathbf{N}\end{array}$ & SBN & MSL & SMS & FL & MRL & ST & SPS & TSW & OC & BYPP & HI & SYPP \\
\hline Replication & 2 & 1.20 & 18.50 & 138.67 & 0.30 & 0.20 & 66.60 & 0.62 & 6.41 & 5.70 & 0.013 & 0.30 & 0.15 & 0.03 & 19.45 & 34.30 & 1.30 \\
\hline Treatment & 9 & 61.30 & $\underset{*}{89.87^{*}}$ & $\begin{array}{c}1543.4 \\
0^{* *}\end{array}$ & 4.86 & $\underset{* *}{29.30}$ & $\begin{array}{c}389.6 \\
7^{* * *}\end{array}$ & $\begin{array}{c}120.9 \\
7^{* * *}\end{array}$ & 17.90 & 45.85 & 0.010 & 10.39 & $0.90^{* *}$ & 2.15 & $607.79^{* *}$ & 202.45 & $30.49^{* *}$ \\
\hline Parents & 3 & 2.89 & 6.31 & 304.63 & 0.67 & $8.49^{* *}$ & 53.20 & 46.32 & 27.90 & 13.20 & 0.010 & $8.44^{*}$ & $0.74^{* *}$ & 1.60 & $530.70^{* *}$ & $12 \underset{*}{1.96}$ & $75.80^{* *}$ \\
\hline Crosses & 5 & 11.40 & $91.29^{*}$ & $\begin{array}{c}1075.7 \\
4^{* *}\end{array}$ & 4.06 & 41.16 & $\begin{array}{c}523.9 \\
5^{* *}\end{array}$ & $\begin{array}{c}143.5 \\
7^{* * *}\end{array}$ & 15.00 & 16.47 & 0.011 & 13.42 & $1.18^{* *}$ & 1.84 & $297.89^{* * *}$ & 193.79 & $2.22^{* *}$ \\
\hline $\begin{array}{c}\text { Parents vs } \\
\text { Crosses }\end{array}$ & 1 & $\begin{array}{c}486.7 \\
8^{* *}\end{array}$ & $\begin{array}{c}333.4 \\
7^{* *}\end{array}$ & $\begin{array}{c}7597.9 \\
8^{* * *}\end{array}$ & $\begin{array}{l}21.4 \\
3^{* * *}\end{array}$ & 32.51 & $\begin{array}{c}727.8 \\
2^{* *}\end{array}$ & $\begin{array}{c}231.8 \\
0^{* * *}\end{array}$ & 1.90 & $\begin{array}{c}290.7 \\
3^{* * *}\end{array}$ & 0.022 & 1.10 & 0.01 & 5.37 & $\underset{* *}{2388.86}$ & 487.50 & $35.93^{* *}$ \\
\hline Error & 18 & 2.57 & 7.58 & 77.47 & 0.30 & 1.23 & 27.60 & 4.60 & 18.52 & 5.02 & 0.05 & 0.70 & 0.10 & 1.05 & 63.50 & 36.95 & 0.42 \\
\hline
\end{tabular}

Table.2 Analysis of variance (ANOVA) for combining ability in a 4 x 4 half diallel cross for 16 quantitative characters in Indian mustard Brassica juncea (L) Czern \& Coss

\begin{tabular}{|c|c|c|c|c|c|c|c|c|c|c|c|c|c|c|c|c|c|}
\hline & df & FF & DM & PH & PBN & SBN & MSL & SMS & FL & MRL & ST & SPS & TSW & OC & BYPP & HI & SYPP \\
\hline GCA & 3 & 0.90 & $10.92^{*}$ & 30.43 & 0.24 & $6.66^{* *}$ & 12.84 & $15.33^{* *}$ & 13.30 & 0.43 & 0.03 & $4.51^{* *}$ & $0.19^{* *}$ & 1.00 & $150.26^{* *}$ & 16.45 & $21.13^{\text {** }}$ \\
\hline SCA & 6 & $30.24^{* *}$ & $39.47^{* *}$ & $756.48^{* *}$ & $2.31^{* *}$ & $11.32^{* *}$ & $188.41^{* *}$ & $52.82^{* *}$ & 2.27 & $22.70^{* * *}$ & 0.04 & $2.96^{* *}$ & $0.35^{* *}$ & 0.57 & $228.76^{* *}$ & $93.00^{* * *}$ & $4.68^{* *}$ \\
\hline Error & 18 & 0.86 & 2.52 & 25.82 & 0.10 & 0.41 & 9.19 & 1.52 & 6.17 & 1.67 & 0.02 & 0.24 & 0.02 & 0.35 & 21.17 & 12.31 & 0.14 \\
\hline
\end{tabular}

Significant at $\mathrm{P}=5 \%$ and ${ }^{* *}$ Significant at $\mathrm{P}=1 \%$

$\mathbf{F F}=$ Days to $50 \%$ flowering, $\mathbf{D M}=$ Days to maturity, $\mathbf{P H}=$ Plant height, $\mathbf{P B N}=$ Primary branch number, $\mathbf{S B N}=$ Secondary branch number, $\mathbf{M S L}=\mathbf{M a i n}$ shoot length, $\mathbf{S M S}=$ Siliqua on main shoot, $\mathbf{F L}=$ Foot length, $\mathbf{M R L}=$ Maximum root length, $\mathbf{S T}=$ Stem thickness, $\mathbf{S P S}=\mathrm{Seeds}$ per siliqua, $\mathbf{T S W}=\mathrm{Thousand}$ seed weight, $\mathbf{O C}=$ Oil content, $\mathbf{B Y P P}=$ Biological yield per plant, $\mathbf{H I}=$ Harvest index, $\mathbf{S Y P P}=$ Seed yield per plant. 
Table.3 Combining ability variances for 16 characters in a 4 x4 half diallel set of Indian mustard Brassica juncea (L) Czern \& Coss

\begin{tabular}{|c|c|c|c|c|c|c|c|c|c|c|c|c|c|c|c|c|}
\hline $\begin{array}{c}\text { Varianc } \\
\text { e }\end{array}$ & FF & DM & PH & $\begin{array}{c}\mathbf{P B} \\
\mathbf{N}\end{array}$ & SBN & MSL & SMS & FL & $\begin{array}{c}\text { MR } \\
\text { L }\end{array}$ & ST & SPS & $\begin{array}{l}\text { TS } \\
\text { W }\end{array}$ & OC & BYPP & HI & $\begin{array}{c}\text { SYP } \\
\text { P }\end{array}$ \\
\hline$\sigma_{g}^{2}$ & $\begin{array}{c}0.00 \\
1\end{array}$ & 1.40 & 0.77 & 0.23 & 1.04 & 0.61 & 2.30 & 1.18 & -0.21 & 0.01 & $\begin{array}{c}0.7 \\
1\end{array}$ & 0.03 & $\begin{array}{c}0.1 \\
1\end{array}$ & 21.52 & 0.69 & 2.74 \\
\hline$\sigma_{s}^{2}$ & $\begin{array}{c}29.3 \\
8\end{array}$ & $\begin{array}{c}36.4 \\
7\end{array}$ & $\begin{array}{c}730.1 \\
8\end{array}$ & 2.21 & $\begin{array}{c}10.9 \\
1\end{array}$ & $\begin{array}{c}179.2 \\
2\end{array}$ & $\begin{array}{c}51.3 \\
0\end{array}$ & -3.9 & 21.03 & 0.02 & $\begin{array}{c}2.7 \\
2\end{array}$ & 0.33 & $\begin{array}{c}0.2 \\
2\end{array}$ & $\begin{array}{c}207.5 \\
9\end{array}$ & $\begin{array}{c}80.6 \\
9\end{array}$ & 4.54 \\
\hline$\sigma_{e}^{2}$ & 0.86 & 2.52 & 25.82 & 0.10 & 0.41 & 9.19 & 1.52 & 6.17 & 1.67 & $\begin{array}{c}.0 .0 \\
2\end{array}$ & $\begin{array}{c}0.2 \\
4\end{array}$ & 0.02 & $\begin{array}{c}0.3 \\
5\end{array}$ & 21.17 & $\begin{array}{c}12.3 \\
1\end{array}$ & 0.14 \\
\hline$\sigma_{g / \sigma}^{2} \sigma_{s}^{2}$ & 0.00 & 0.04 & 0.01 & 0.10 & 0.02 & 0.03 & 0.04 & $\begin{array}{c}- \\
0.30\end{array}$ & -0.01 & 0.05 & $\begin{array}{c}0.2 \\
6\end{array}$ & 0.01 & $\begin{array}{c}0.4 \\
9\end{array}$ & 1.03 & 0.01 & 0.60 \\
\hline
\end{tabular}

*Significant at $\mathrm{P}=5 \%$ and ${ }^{* *}$ Significant at $\mathrm{P}=1 \%$

Table.4 General combining ability (GCA) effects of parents for 16 characters in 4X4 half diallel set of Indian mustard Brassica juncea $(\mathrm{L})$ Czern \& Coss

\begin{tabular}{|c|c|c|c|c|c|c|c|c|c|c|c|c|c|c|c|c|}
\hline Parents & FF & DM & PH & PBN & SBN & MSL & SMS & FL & MRL & ST & SPS & TSW & $\mathbf{O C}$ & BYPP & HI & SYPP \\
\hline PM27 & $\begin{array}{c}- \\
0.44\end{array}$ & 0.92 & $\begin{array}{c}- \\
1.98\end{array}$ & $-0.29^{*}$ & $1.28^{* * *}$ & -1.22 & $-0.95^{*}$ & 1.32 & -0.34 & 0.01 & 0.1 & $-0.12^{*}$ & -0.22 & -2.71 & $\begin{array}{c}- \\
1.92\end{array}$ & $1.22^{-}$ \\
\hline Pusa Mahek & 0.50 & 1.14 & 3.19 & 0.13 & $1.02^{* *}$ & -0.82 & $2.36^{* * *}$ & -0.27 & 0.08 & 0.03 & $-1.2^{* *}$ & $0.24^{* *}$ & $\overline{-}^{-}{ }^{*}$ & $7.45^{* *}$ & 2.05 & $2.75^{* *}$ \\
\hline TM-2 & $\begin{array}{c}- \\
0.05\end{array}$ & $1.8^{-}$ & 0.17 & 0.14 & $0.68^{* *}$ & -0.02 & -0.44 & $-1.98^{*}$ & 0.29 & -0.02 & $0.40^{*}$ & 0.02 & 0.34 & -1.68 & $\begin{array}{c}- \\
0.45\end{array}$ & $1.15^{* *}$ \\
\hline DRMR-150-35 & 0.01 & $\begin{array}{c}- \\
0.25\end{array}$ & $\begin{array}{c}- \\
1.02\end{array}$ & 0.02 & -0.42 & 2.06 & $-0.97^{*}$ & 0.93 & -0.02 & -0.01 & $0.80^{* *}$ & $-0.14^{*}$ & 0.33 & -3.06 & 0.33 & $-0.37^{*}$ \\
\hline $\mathrm{SE}(\mathrm{gi}) / \mathrm{CD} 5 \%$ & 1.04 & 1.78 & 5.71 & 0.35 & 0.72 & 3.41 & 1.39 & 2.79 & 1.45 & 0.48 & 0.54 & 0.17 & 0.66 & 5.17 & 3.90 & 0.42 \\
\hline SE(gi-gj) & 1.70 & 2.91 & 9.33 & 0.58 & 1.17 & 5.57 & 2.27 & 4.56 & 2.67 & 0.07 & 0.89 & 0.28 & 1.08 & 8.45 & 6.40 & 0.69 \\
\hline
\end{tabular}

* Significant at $\mathrm{P}=5 \%$ and ${ }^{* * *}$ Significant at $\mathrm{P}=1 \%$,

$\mathbf{F F}=$ Days to $50 \%$ flowering, $\mathbf{D M}=$ Days to maturity, $\mathbf{P H}=$ Plant height, $\mathbf{P B N}=$ Primary branch number, $\mathbf{S B N}=\mathbf{S e c o n d a r y}$ branch number, $\mathbf{M S L}=\mathbf{M a i n}$ shoot length, $\mathbf{S M S}=$ Siliqua on main shoot, $\mathbf{F L}=$ Foot length. $\mathbf{M R L}=$ Maximum root length, $\mathbf{S T}=\mathrm{Stem}$ thickness, $\mathbf{S P S}=\mathrm{Seeds}$ per siliqua, $\mathbf{T S W}=\mathrm{Thousand}$ seed weight, $\mathbf{O C}=$ Oil content, $\mathbf{B Y P P}=$ Biological yield per plant, $\mathbf{H I}=$ Harvest index, $\mathbf{S Y P P}=\mathrm{Seed}$ yield per plant 
Table.5 Estimates of Specific combining ability (SCA) effects of $F_{1}$ progeny for 16 characters in 4 X 4 half diallel set of Indian mustard Brassica juncea (L) Czern \& Coss

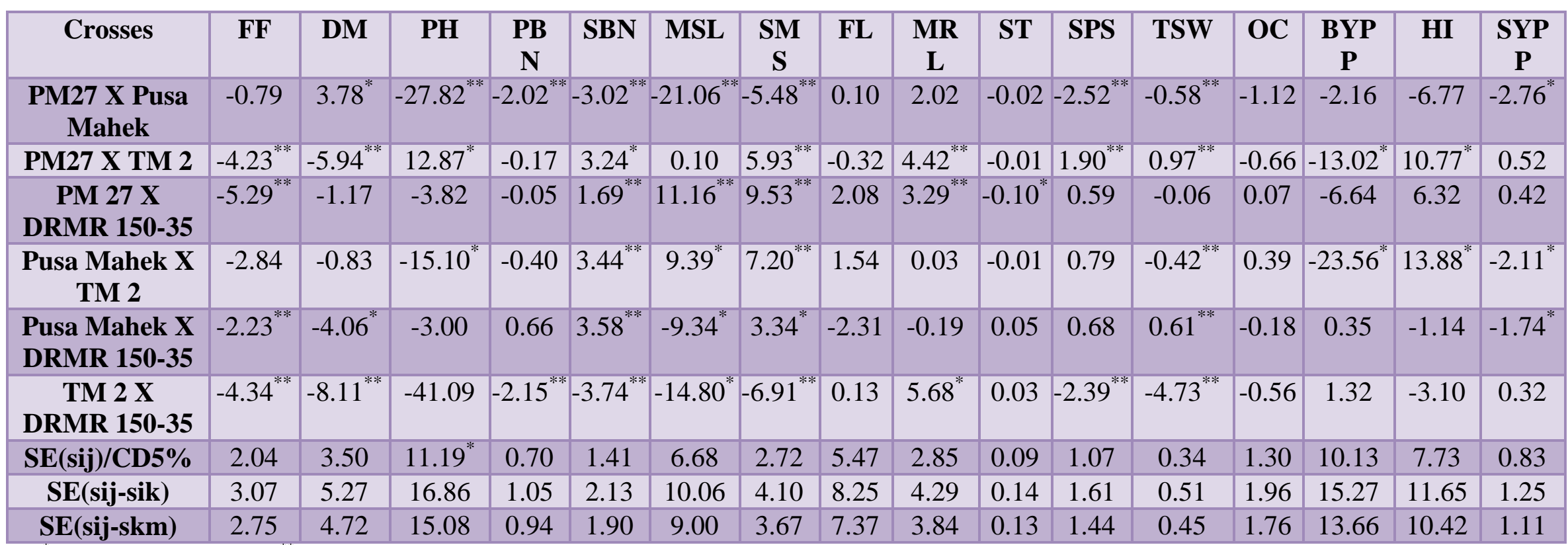

*Significant at $\mathrm{P}=5 \%$ and ${ }^{* *}$ Significant at $\mathrm{P}=1 \%$,

$\mathbf{F F}=$ Days to $50 \%$ flowering, $\mathbf{D M}=$ Days to maturity, $\mathbf{P H}=$ Plant height, $\mathbf{P B N}=$ Primary branch number $\mathbf{S B N}=$ Secondary branch number, $\mathbf{M S L}=$ Main shoot length, $\mathbf{S M S}=$ Siliqua on main shoot, $\mathbf{F L}=$ Foot length. $\mathbf{M R L}=$ Maximum root length, $\mathbf{S T}=\mathrm{Stem}$ thickness, $\mathbf{S P S}=\mathrm{Seeds}$ per siliqua, $\mathbf{T S W}=\mathbf{T h o u s a n d}$ seed weight $\mathbf{O C}=$ Oil content, $\mathbf{B Y P P}=$ Biological yield per plant, $\mathbf{H I}=$ Harvest index, $\mathbf{S Y P P}=$ Seed Yield Per Plant 
Table.6 Estimates of Heterosis for 16 characters in 4 X 4 half diallel set of Indian mustard Brassica juncea (L) Czern \& Coss

\begin{tabular}{|c|c|c|c|c|c|c|c|c|c|c|c|c|c|c|c|c|}
\hline Crosses & FF & DM & PH & PBN & SBN & MSL & SMS & FL & MRL & ST & SPS & TSW & $\mathrm{OC}$ & BYPP & HI & SYPP \\
\hline $\begin{array}{l}\text { PM27 X Pusa } \\
\text { Mahek }\end{array}$ & $-9.32^{*}$ & 2.02 & $-34.61^{*}$ & $-55.56^{*}$ & $-36.46^{*}$ & $-53.13^{*}$ & $-16.85^{*}$ & -1.74 & 12.92 & -4.70 & $-36.53^{*}$ & $-25.79^{*}$ & $-5.46^{*}$ & $-37.33^{*}$ & $-29.03^{*}$ & $-55.41^{*}$ \\
\hline PM27 X TM 2 & $-8.22^{*}$ & $-9.20^{*}$ & -6.90 & $-30.26^{*}$ & $29.67^{*}$ & -5.98 & $27.53^{*}$ & -8.31 & $56.01^{*}$ & -10.07 & 15.69 & $19.34^{*}$ & -2.33 & $-59.02^{*}$ & $83.26^{*}$ & $-4.25^{*}$ \\
\hline $\begin{array}{c}\text { PM } 27 X \\
\text { DRMR 150-35 }\end{array}$ & $-21.08^{*}$ & $-5.63^{*}$ & $-18.63^{*}$ & $-20.00^{*}$ & 21.24 & 2.33 & $41.69^{*}$ & 7.44 & $46.62^{*}$ & $-16.11^{*}$ & -6.17 & $-195.15^{*}$ & -1.99 & & 19.54 & $-10.31^{*}$ \\
\hline $\begin{array}{l}\text { Pusa Mahek X } \\
\text { TM } 2\end{array}$ & $-14.55^{*}$ & -4.51 & -25.63 & $-27.18^{*}$ & $53.79^{*}$ & -0.46 & $18.64^{*}$ & -1.64 & 6.04 & -5.44 & -5.85 & & -2.04 & & $52.52^{*}$ & \\
\hline $\begin{array}{l}\text { Pusa Mahek X } \\
\text { DRMR 150-35 }\end{array}$ & $-13.86^{*}$ & $-7.89^{*}$ & $-18.66^{*}$ & -5.56 & $44.40^{*}$ & $-27.18^{*}$ & $6.81^{*}$ & -10.91 & 3.20 & 3.40 & -15.28 & 0.45 & -3.17 & & -0.73 & \\
\hline $\begin{array}{c}\text { TM } 2 \text { X } \\
\text { DRMR 150-35 }\end{array}$ & $-18.67^{*}$ & $-13.80^{*}$ & $-41.62^{*}$ & $-55.90^{*}$ & $-37.73^{*}$ & $-33.40^{*}$ & $-13.98^{*}$ & -8.66 & $65.82^{*}$ & 1.08 & $-27.08^{*}$ & -16.08 & -2.40 & $-32.95^{*}$ & $-11.52^{*}$ & $-10.68^{*}$ \\
\hline
\end{tabular}

"Significant at $\mathrm{P}=5 \%$ and ${ }^{* *}$ Significant at $\mathrm{P}=1 \%$,

$\mathbf{F F}=$ Days to $50 \%$ flowering, $\mathbf{D M}=$ Days to maturity, $\mathbf{P H}=$ Plant height, $\mathbf{P B N}=$ Primary branch number $\mathbf{S B N}=$ Secondary branch number, $\mathbf{M S L}=$ Main shoot length, $\mathbf{S M S}=$ Siliqua on main shoot, $\mathbf{F L}=$ Foot length. $\mathbf{M R L}=$ Maximum root length, $\mathbf{S T}=$ Stem thickness, $\mathbf{S P S}=$ Seeds per siliqua, $\mathbf{T S W}=\mathrm{Thousand}$ seed weight $\mathbf{O C}=$ Oil content, $\mathbf{B Y P P}=$ Biological yield per plant, $\mathbf{H I}=$ Harvest index, $\mathbf{S Y P P}=$ Seed Yield per Plant 
The heterosis and combining ability studies revealed that the genotype TM-2 showed high negative GCA effects for days to maturity and foot length whereas the variety Pusa Mahek was found to be a valuable parent in crosses for most of the yield and yield attributing characters. The cross PM-27 x TM-2 was best cross combination showing significantly high SCA and heterosis effect for several yield attributing traits

Hence, the two genotypes TM-2 and Pusa Mahek can be used as potential parents for combining desirable characters such as early maturity as well as enhancing seed yield through heterosis in future crop improvement programmes.

\section{References}

Aghao, R.R., Nair, B., Kalamkar, V. and Bainade, P.S. (2010). Diallel analysis for yield and yield contributing characters in Indian mustard (Brassica juncea). J. Oilseed Brassica 1(2): 7578.

Anonymous, (2017): Executive summary rapeseed-mustard crop survey 201617, GOI.

Brar, K.S., Yadav, M.S., Mittal, V.P. and Singh, P. (2006). Combining ability for seed yield, its component characters and oil content in toria. Crop Improv. 33(2): 185-189.

Brandle J E, McVetty P B E (1989). Heterosis and combining ability in hybrids derived from oilseed rape cultivars and inbred lines. Crop Sci, 29: 1191-1195

Falconer, D.S (1960) Introduction to quantitative genetics. Oliver and Boyd, Edinburgh

Gami, R.A. and Chauhan, R.M. (2013). Heterosis and combining ability analysis for seed yield and its attributes in Indian mustard (Brassica juncea L.). Indian J. Agric. Sci. 47(6): 535-539.
Griffing, B. (1956). Concept of general and specific combining ability in relation to diallel crossing system. Aust. J. Biol. Sci. 9: 463-493.

Gupta, P., Chaudhary, H. B. and Lal, S. K. (2011). Heterosis and combining ability analysis for yield and its components in Indian mustard (Brassica juncea L. Czern \& Coss). Academic J. Plant Sci. 4(2): 45-52.

Kumar, P., Yadava, T.P., Raj, L., Gupta, S.K. and Thakral, N.K. (2001). Combining ability and heterosis for oil content in toria (Brassica campestris L.). Crusiferae Newsl. 19: 87-88.

Monalisa, P., Singh, N.B., Singh, N.G. and Laishram, J.M. (2005). Genetic divergence and combining ability in relation to heterosis in Indian mustard [Brassica juncea (L.) Czern. and Coss.] for seed yield, its attributes and oil yield. Indian J. Genet. 65(4): 302304.

National Agricultural Statistical Service, (2013) USDA

Parmar S.A., Jaimini, S.N. and Ram, B. (2011). Combining ability analysis for seed yield and its components over environments in Indian mustard (Brassica juncea L.). J. Oilseed Brassica 2(2): 61-66.

Shrimali, T.M., Chauhan, R.M., Gami, R.A. and Patel, P.T. (2016). Diallel analysis in Indian mustard (Brassica juncea L. Czern \& Coss.). Electr. J. Plant Breed. 7(4): 919-924.

Singh, M., Singh, L. and Srivastava, S.B.L. (2010). Combining ability analysis in Indian mustard (Brassica juncea L. Czern \& Coss). J. Oilseed Brassica 1(1): 23-27.

Sprague G.F. and Tatum L.A. (1942) General versus specific combining ability in single crosses of corn. J. Amer. Soc. Agron. 34: 923-924

Teklewold A, Becker H C (2005). Heterosis 
and combining ability in a diallel cross of Ethiopian mustard inbred lines. Crop Sci, 45(6): 2629-2635

Thanmichon, S. (2015). Combining ability analysis of Indian Mustard [Brassica juncea (L) Czern and Coss]. Master degree thesis submitted to Assam Agricultural University, Jorhat, Assam.
Yadava, D.K., Singh, N., Vasudev, S., Singh, R., Singh, S., Giri, S.C., Dwivedi, V.K. and Prabhu, K.V. (2012). Combining ability and heterobeltiosis for yield and yield contributing traits on Indian mustard (Brassica juncea). Indian J. Agric. Sci. 82(7): 563-567.

\section{How to cite this article:}

Vidyut Kumar Saikia, Rumjhum Phukan, Hrishikesh Ojah, Purna Kanta Barua, Meghali Barua and Prakash Kalita. 2019. Heterosis and Combining Ability Analysis for Seed Yield and its Attributes in Indian Mustard [Brassica juncea (L.) Czern and Coss]. Int.J.Curr.Microbiol.App.Sci. 8(12): 1090-1099. doi: https://doi.org/10.20546/ijcmas.2019.812.138 